\title{
Translational Japanese: A Transformative Strangeness Within
}

\author{
Judy Wakabayashi, Kent State University
}

\section{Introduction}

In Japan there has long been an acceptance, and even a welcoming, of language with a distinctly 'foreign' origin and texture. Openness toward this foreign-tinged style in translations into Japanese, and in original writing influenced by translations, contrasts with the inward-looking expectation in Anglophone circles that translations should sound smooth and natural in the target language. The relative pervasiveness of this foreign-influenced style of written Japanese has given rise to talk of a liminal 'third language' that exists between the various source (foreign) languages and the target language (Japanese), as well as talk of a 'third literature' that is neither entirely foreign nor entirely indigenous in nature. In this article, I probe the notion of translational language in the Japanese context, identifying some recurring features and examining how it differs from 'translationese' in its causes, motivations, and how it is perceived. The influence of translational language is also explored, including its use in original Japanese writing. As I argue, attitudes toward translational language are not only genredependent but have changed over time, with translational language becoming a more important and integrated part of the Japanese language even as it has attracted criticism. I conclude the article with a discussion of the putative 'betweenness' that is often problematically ascribed to translational language. The question is whether translational language in the Japanese context lies between the source language(s) and Japanese (that

PORTAL Journal of Multidisciplinary International Studies, vol. 6, no. 1, January 2009.

'The Space Between: Languages, Translations and Cultures': Special Issue edited by Vera Mackie, Ikuko Nakane, and Emi Otsuji. 
is, external to both) or whether it is a part of the Japanese language. I suggest that translational language does not constitute a language 'between' the source and target languages; rather, it is an integral part of the Japanese language and an innovative force that has contributed to the modernization of the Japanese language, literature and thinking, while translation as a whole elides the boundaries that artificially demarcate source and target languages. Nor are translators neutral entities 'between,' but figures committed to a particular cultural framework, however that might be defined.

\section{Translational language}

In 1813 the German theologian Friedrich Schleiermacher argued that 'any language into which so many works are translated harbours a special domain just for translations, and much must be allowed them that would not otherwise be permitted to see the light of day' (1997: 238). Quite independently from Schleiermacher, Japanese translators have put this idea into practice, albeit without the nationalist agenda of Schleiermacher. This special translational style is known as hon'yakuchō. Although the term is sometimes rendered in English as translationese, its pejorative associations do not apply in the Japanese context. The term 'third code,' as used in the Dictionary of Translation Studies (Shuttleworth \& Cowie 1997: 173), seems more appropriate, although the idea of a code separate from (between) the source and target codes is problematic, as discussed below. Shuttleworth and Cowie comment that "the term third code generally denotes more subtle deviations from TL linguistic norms, and its use implies on the part of the writer ... a lack of disapproval ... the third code can extend and enrich the linguistic repertoire' of the target language (1997: 173). A relative lack of disapproval and the extension of the linguistic repertoire are features of hon'yakuchō, which consists of language with a recognizably translational origin or influence. The fact that this usage is often intentional differentiates it from translationese, which is the default retention of source language features as a result of negative interference or translator incompetence. (Admittedly, without a translator's foreword, for instance, it is often difficult to determine cause and motivation.)

Translations exhibiting distinctive source-derived features, or features used with different frequency from original texts, are by no means unique to Japan. What characterizes the Japanese situation is the degree of acceptance of such features, particularly in certain genres, such as legal texts (arguably including the 1947 
Constitution), textbooks and academic writing, and some literature. Translational language is regarded in Japan as having value in its own right, and despite occasional criticism there is no strong norm against sounding like a translation. ${ }^{1}$ What makes hon'yakuchō of particular interest is its contribution to shaping the Japanese language, literature and even thinking.

\section{Linguistic markers of hon'yakuchō}

Hon'yakuchō is signalled by the (co-)presence of certain recurring features, including a range of common lexical features. ${ }^{2}$ Roundabout expressions and unusual wording (atypical collocations) include kaigi o motsu (to hold a meeting), shōri ni you (to be drunk with victory) and kanjō ni shihai sareru (dictated by emotion). Some of these expressions have become so common that they no longer seem unusual (for example, $A$ bakari de wa naku $B$ [not only A, but also B]; $A$ de areba aru hodo $B$ [the more $\mathrm{A}$, the more B]). There is a higher-than-usual frequency of katakana loanwords, and a higherthan-usual proportion of difficult Chinese compounds, particularly as nouns. Many of these nouns were devised as equivalents of European words (for example, $k \bar{s} s a t s u$ as an equivalent of consideration). Shifts in meaning are another recurrent lexical feature. Some existing Japanese words changed meaning when they were adapted for use as equivalents of imported words. One oft-cited example is jiyzu. Nakamura Keiu's 1872 translation of John Stuart Mill's On Liberty as Jiyū no ri played a decisive role in establishing jiy $\bar{u}$ as the translation of 'liberty.' In traditional Japanese usage jiy $\bar{u}$ had meant selfishness, egoism or 'license,' but it came to be used as a sociopolitical concept (see chapter 4 in Howland 2002 for an in-depth discussion). Although this particular translational equivalent has become thoroughly naturalized, the cumulative effect of similar semantic shifts over the past century or so as the result of putting existing words to new uses, combined with loanwords and newly coined words, has nudged the Japanese language off its previous trajectory. This is, of course, a natural part of

\footnotetext{
${ }^{1}$ A similar situation apparently exists in China. Chang (1998: 266) maintains that in China 'linguistic and stylistic peculiarities in translations are deemed not only inevitable and normal, but even desirable to a certain extent as their very presence is proof that there is a self-effacing translator letting the original author speak without his/her intervention. On the other hand, acceptability-oriented strategies that make the target text read like an original rather than the original will immediately arouse suspicion that the translator has intervened.'

${ }^{2}$ Miura's discussion (1979) of the influence of English on Japanese grammar also includes the 'translation passive' (no longer regarded as foreign), personification, beki and beku as equivalents of the to-infinitive, cognate objects, new ways of expressing comparisons, and the use of Chinese-derived affixes (for example, teki) to translate English affixes.
} 
linguistic evolution, but the scale and rapidity of this change in Japan was remarkable, and until these new usages became fully assimilated they added to the foreign air of texts in which they appeared.

Common grammatical features of hon 'yakuchō include the frequent use and repetition of explicit subjects, which interrupt the cohesion and flow of thought enabled by the implicit subjects typical of traditional Japanese writing, where the focus is instead on the predicate. In particular, inanimate entities - for example, denwa (phone) —including abstract nouns — for example, hōki (abandonment) — could not traditionally act as the subject. In the 1960s, Ikeyama (1963: 221) commented that abstract words had still not been integrated into Japanese writing. Two decades later, however, they had greater acceptance, leading Yoshida (1985: 101) to state that literal translations of inanimate subjects had a particular impact on literature and provided new ways of thought. For instance, they can be used in dialogue to convey the impression that a speaker is tense, and they might indicate that events are unfolding regardless of the speaker's intentions (Yoshida 1985: 117-18). Nevertheless, suggested Yoshida, the use of inanimate subjects still sometimes created friction with modern Japanese (1985: 126).

Also routine is the increased use of personal and demonstrative pronouns, such as literal equivalents of it-for example, Sore wa aru atatakai haru no hi datta. Many translations feature a higher frequency of the second-person pronoun omae than in original writing, and the translational equivalents kare (he) and kanojo (she) have become common since the Meiji period, even though originally there were no thirdperson personal pronouns in Japanese. ${ }^{3}$ The reflexive form sore jitai (in itself) was coined under the influence of translations of European texts and initially had a very novel ring. Another common feature is the use of tokoro no as an equivalent of relative pronouns-for example, fukushi ni kanshite kokka ga toru tokoro no gensoku (the principles that the state adopts towards social welfare). Schepers (1989: 56) has argued that the introduction of features such as relative pronouns, and expressions creating subordinate clauses, 'allows more precise and logical statements and an expression of the subject-object dichotomy.'

\footnotetext{
${ }^{3}$ See Yanabu (1998: 54) and Levy (2006: 165-68). Yanabu maintains that it is questionable whether personal pronouns exist in authentic Japanese even today (1998: 16).
} 
Yet more lexical features of hon'yakuchō are long and frequent noun modifiers. In right-branching languages such as English, modifiers follow the noun being modified, but when translated into Japanese, a left-branching language, they precede the noun that is the focus. Thus readers are sometimes forced to reread the text to grasp the meaning properly, and excessive emphasis is placed on the noun head (Yanabu 1978a: 152). To these are added the causative use of adjectives of emotion-for example, ... wa watashi o kanashiku saseru (... makes me sad), instead of the traditional (watashi wa) ...ga kanashiku naru - and new uses of verb forms. For instance, de arō has come to be used not just in the sense of probability, but also as a future marker. Frequent and unnatural use of connectives is also common. Yanabu (1998: 68-70) traces the equating of soshite and shikashi with and and but to the translator-writer Mori Ōgai (1862-1922), who tried to link phrases by connectives, as in Western writing, so as to write more logically. This had a great impact on young writers of the time. Hon 'yakuchō also includes frequent use of logic-related expressions such as naze ni and naze naraba. At least up until Meiji times expressions equivalent to 'because' were not often used in Japanese (Maruyama and Katō 1998: 85).

Stylistic markers of translational language include stiffness and verbosity resulting from a tendency toward explicitness and repetition and a tendency to use many exceptive clauses (Ikeyama 1963: 217-18). The presence of foreign cultural elements and foreign logic - for instance, following English discourse patterns rather than traditional discourse patterns - further heightens the sense of foreignness.

Writing in the late 1970s, Yanabu (1978a: 142) asserted that such features make the translational status of a text apparent to any Japanese reader. More recently, claims as to the readily identifiable nature of translated texts have been tested by Yuri Furuno (2004). She found that not all of the subjects in her study were, in fact, able to distinguish between translated and non-translated texts. Furuno suggests (2005: 153) that one reason might be that hon'yakucho' 'has become such a part of Japanese writing style that readers can no longer tell the difference between the two writing styles.' In a language that accepts everything, it can be difficult to determine what is heterogeneous, and all modern Japanese prose is to some extent translation-style. This openness toward foreign writing belies the oft-heard criticisms of Japanese insularity and suggests that at least in linguistic matters the Japanese are receptive to heterogeneity, even if these imported 
elements are eventually assimilated and transformed. Schäffner and Adab (2001: 169) have argued that even if imported features are present in translations, successful communication requires sufficient authentic features. In the Japanese context, however, one particular mode of 'success' entails exhibiting the qualities of a translation, rather than (just) those of an authentic text.

\section{Possible causes and motivations}

The origins of hon'yakuchō can be traced back to the ways in which Chinese texts were rendered into language retaining Chinese overtones - that is, kanbun kundoku (interpretive readings of Chinese texts) and mixed Sino-Japanese. Thus, when European languages arrived in Japan in the sixteenth century there was a precedent for allowing foreign languages to penetrate and affect Japanese, rather than requiring them to conform fully to Japanese conventions. Just as the practice of reading Chinese texts in accordance with Japanese syntax and glosses gave rise to the style known as kanbunmyaku (Japanese texts with strong Chinese overtones), a somewhat similar practice as applied to the reading of texts in European languages led to the style known as obunmyaku (Japanese texts with strong European overtones ${ }^{4}$ ), and it was this that acted as the forerunner of hon'yakuchō.

There are several possible causes or motivations behind hon'yakuchō. The first is that hon'yakuchō is translationese resulting from incompetence. This certainly is and was far from uncommon, and it has contributed to the prevalence of translational language, but this unintentional form of hon'yakuchō is not our main concern here. Moreover Japan's centuries-long status as a cultural recipient rather than transmitter encouraged an attitude of accommodation with the Other (Kornicki 1998: 18). Japan is not just a receptor culture; it is also a receptive culture. In comments that are equally applicable to Meiji times, Furuno (2005: 147) observes that in postwar Japan, 'acquiring new ideas or information from the West was so important that the 'acceptability' of the product - that is, authenticity and naturalness of the language — was considered to be of secondary

\footnotetext{
${ }^{4}$ According to Egoyama (1964: 134), the following elements constitute ōbun-myaku: passive expressions; expressions using the progressive form; expressions where an inanimate entity, especially an abstract noun, is the subject; fresh metaphors, particularly personification; expressions with a clear subject and predicate (particularly subject); connectives, particularly the use of conjunctions linking sentences together; the use of deictics; expressions that insert an explanation using an em dash; expressions linked by adnominals that are easy to understand if suru tokoro no is added in the function of a relative pronoun; the use of non-traditional punctuation marks; and, other expressions peculiar to European writing.
} 
importance.' Hon 'yakuchō can be interpreted as indicating an openness to linguistic and cultural alterity. Nohara (1998) attributes the acceptance of or demand for hon'yakuchō translations to two factors: Japanese readers actually enjoy the shock of experiencing foreign cultures; and, the widespread belief that a translation using hon'yakuchō reflects more faithfully and transparently 'the author's logic, emotions and thought patterns than one written in more natural Japanese.' Translating foreign works into natural Japanese might conversely impart a sense of dislocation, calling 'undue attention to itself in the most unnatural way of all' (Levy 2006: 217).

In Meiji times the status associated with the ability to comprehend translations of works from such different linguistic and cultural environments was perhaps one factor behind their acceptance. Koyano (1997: 228-29) asserts that even today some translations in Japan are regarded as important precisely because they are so difficult to understand. In a non-Japanese context, Savory (1958: 58-59) has suggested that readers who once knew but have forgotten the language of the original might want a recognizably translational rendition. This perhaps applies in Japan, where most people today have studied (and often largely forgotten) English. Another possibility is that hon'yakuchō is a means of quarantining or even parodying foreignness so as to protect legitimate Japanese writing and keep Japan's Others at arm's length. If that were the intention, it has manifestly failed. Statements by various writers indicating their deliberate adoption of a translational style in order to reinvigorate (rather than conserve) Japanese writing do not support this interpretation.

Alternatively, hon'yakuchō might represent an attempt to subvert the source language and culture. Schäffner and Adab note that 'The effect of dislocation created by the hybrid text may serve to disparage or promote the foreign source culture, text type and use of language, and also the ideological content of the message' (2001: 174). Although a conceivable outcome of hon'yakucho, evidence to suggest that this is a common motivation behind its use is lacking. Another possibility is that hon'yakuchō constitutes an ethical refusal to domesticate foreign texts. Discussing translationese (but without the negative connotations usually associated with that term), Sturrock (1990: 1010) proposes that 'A voluntary 'translationese,' systematically followed, would be ... a drawing of our attention to the irrevocably mediate ['in-between'] status of the language of translation.' I return to this alleged 'mediate status' below. 
The practice of resistant translation deriving from a desire not to 'violate' the original text refers, however, to situations where the target culture is regarded as superior to the source culture (not the typical scenario with translation into Japanese) and where translation is used to resist the effacing of the source culture's otherness. In Japan the emphasis on communicating linguistic and cultural differences lacks these particular ideological overtones. Rather than presenting a resistant or conflictual space, hon'yakuchō is valued for its creative potential. For instance, the domesticated (naturalsounding) translations produced by people such as Uchida Roan, a Meiji critic and writer who was the first Japanese to translate Dostoevsky, prompted a reaction in the early twentieth century in the form of calls for dai-nihongoka ('enlarging,' or enriching the Japanese language ${ }^{5}$ ) by translating in a manner that literally followed the foreign wording in what has been called a neo-literal approach (Kimura 1972: 377). This target orientation differs from a source-oriented respect for Otherness.

A related possibility is that hon'yakuchō constitutes 'foreignization,' which in the specific sense popularized by Venuti (1995) entails an ethical decision to disrupt readers' complacency through a variety of linguistic means already available in the target language. Hon 'yakuchō, however, is not usually motivated by a desire to jar readers or subvert (as distinct from enriching) Japanese language conventions. Moreover, it draws not on the target language, but on the source languages - on linguistic means that were not available in Japanese or were used rarely or in a different function. The end result — defamiliarizing language — does, however, share similarities with that of foreignization. For instance, in his translations of poetry and prose (such as his 1924 rendition of Paul Morand's novel Ouvert la Nuit, titled Yoru hiraku), Horiguchi Daigaku boldly injected the expressions of a different language system into Japanese, without trying to graft them onto the Japanese language forcibly, or he incorporated them as similes, creating a new style that differed from that of the original and had a great impact (Watanabe 1982: 386).

Hon 'yakuchō might represent an instance of exoticism, but not in the sense usually associated with translation into modern Western languages, which implies grasping or mastering the (inferior) other as a textual object. Instead the 'exotic textual other' is

\footnotetext{
${ }^{5}$ This was opposed to shō-nihongoka ('making the Japanese language smaller'), which signified translating into fluent, smooth Japanese.
} 
recognized as 'an ontologically superior linguistic alterity' (Levy 2006: 15). The outcome is 'a distinctly exoticist desire to identify with but not assimilate the foreign' (215). Levy (224-25) quotes Shimamura Hōgetsu's observation in 1912 that because of the resulting foreign atmosphere,

\begin{abstract}
we are able to grasp a work's power, flavor, and the like by entering into details that would elude our attention had we simply glided over the words ... In other words, it is possible to make a work stronger by borrowing the help of the foreign scent, namely, exoticism ... Put in positive terms, this is a more profound way of savoring the work; in negative terms, it is an overestimation of the work's value.
\end{abstract}

These complex and sometimes contradictory possibilities (for instance, does hon'yakuchō function to welcome heterogeneity or to keep it at a safe distance?) suggest that there is more to hon'yakucho than what is typically associated with translationese or foreignization.

\title{
The outcome
}

Regardless of the motivation, hon 'yakuchō has had a significant impact on translations and original writing in Japan, where the domesticating impulse common in AngloAmerican translation circles has long been subordinated to more foreign-tinged approaches. Intentional or otherwise, the outcome has been innovation. The nontraditional features embodied in hon'yakuchō have often struck Japanese readers not as second-rate but as fresh, and they have reshaped the Japanese language. In a nonJapanese context Devy (1998: 62) argues that 'Collectively, many translations create a convention of linguistic compromises, which then becomes a sub-system within the TL [target language]. Depending on the cultural importance of the kind of works translated, such a sub-system or systems may come to occupy a more central position within the dominant literary dialect of the TL.' This is precisely what occurred in Japan. It should be noted, however, that the process of incorporating foreign influences can result in both enrichment and endangerment of the target language. Achieving a balance is difficult, even if there were agreement on the nature of such a balance. ${ }^{6}$

Tanaka (1982: 194) has argued that if translation is an act of betrayal, as has often been suggested, then the betrayal (which might be interpreted here as contamination from the source language) is greatest when European languages are translated into Japanese,

\footnotetext{
${ }^{6}$ Isoya (1978: 9) suggests that hon'yaku-chō is regarded in a negative light if the result is no good and as 'new' Japanese if the result is good. This is a circular argument, because no criteria are given for determining whether the result is good or not.
} 
because of the radical linguistic differences. Tanaka's implication that the proportion of negative transfer is a function of linguistic difference does, however, overlook other potentially relevant aspects. For instance, Toury (1995: 278) maintains that tolerance of interference might depend on the relative power between source and target cultures, with greater tolerance when the source language or culture has more prestige than the target culture. Japanese readers, however, seem to have not just tolerated but accepted translational language largely irrespective of the status in Japan of the source languages or cultures. Kobayashi (1995: 26) argues that no matter how diverse the source languages, they all end up sounding the same in hon'yakuchō. Although he does not elaborate on or substantiate this claim, possible reasons might relate to the fact that the main source languages in modern Japanese translation history have been European languages that do, in fact, have genetic ties, leading to certain similarities when they are rendered into Japanese. Another possibility might be that over time certain standard renditions and usages, such as those mentioned above, have developed as part of the repertoire of Japanese translators, with stock expressions and structures being associated with the act of translation itself, rather than with a particular source language.

Achieving acceptance as a translator in Japan, then, might derive at least in part from conforming to these norms of translation, rather than from measuring up to the norms of more autochthonous Japanese. In other words, regardless of source language this similarity might reflect a desire to 'mark' translations as such, even if not to the extent of quarantining them from other types of writing. The relative homogeneity among translations seems to stem from Japanese expectations of, and respect for, translations per se, rather than the relative prestige of particular source languages or cultures. The long contact with translational language in the context of Western works seems to have engendered a perception that 'this is what translations are like,' and this has spilled over into translations from languages and cultures not necessarily regarded as prestigious. The upshot is that Japanese translations from diverse languages arguably bear a certain resemblance to each other, constituting a subsystem shaped by the very fact of translation, rather than by factors associated with the source language or culture.

Toury (1995: 278) suggests that tolerance of interference is also likely to be affected by the prestige of different text types. In Meiji Japan the impact of translational language was of particular importance in translated literature and even in original literature (see 
next section). More specifically, Inoue notes that 'In the early Shôwa era ... this style came to be widely accepted as the style of anthologies of world literature. By and by, it influenced the literary style of the generation of authors born in the 1930s and 1940s, who grew up reading literature translated in this way' (1996: 5). Contemporary readers of translated literature, notably the more popular genres, have greater expectations of idiomaticity, but what today is regarded as idiomaticity has been influenced to a great extent by what in earlier decades was distinct from the idiom of the time.

Translational language has also been widespread in academic translations, perhaps because in such works the interest in content outweighs concerns over unnaturalness, although these stilted renditions have also attracted their share of criticism. An example of translational language in an original academic work is the following extract from Hirano Yoshitarō's Nihon shihonshugi shakai no kikō (The structure of Japanese capitalist society; 1934), in a reference to Prussia's outwardly constitutionalist parliament: 'ippō de wa, tsuika sareta kanfu toshite no ichi kōsei bubun o nashi zenjinmin ni tairitsu suru to tomo ni, tahō de wa, sono gaikenteki jidōsei ni oite, $\underline{\text { burujoa }}$ shakai no genjitsu o, sono keishiki no uchi ni kaishō suru. ${ }^{, 7}$ Markers of the translational style here include the overall density resulting from the high proportion of Chinesebased words relative to native Japanese words (the use of zen-jinmin to signify the concept of all the people), the use of opaque vocabulary such as jidosei (self-identical sameness), and opaque wording such as the underlined section ('[it] resolves the reality of bourgeois society within its form').

Literature and academic writing both constitute prestigious genres, which might lead to the expectation of greater resistance to translational writing. The fact that this has not been the case is a further indicator of the prestige associated with foreign-influenced language in Japan. At the level of more quotidian texts and popular literature, however, the demand for enjoyment and/or easy access to the content unhindered by the challenges presented by translational language has resulted in a preference for more natural Japanese.

\footnotetext{
${ }^{7}$ Although no translation into English can fully convey the flavor of this passage, it reads roughly as follows: 'On the one hand, together with constituting one component part of the government as an added government office and being opposed to all the people, on the other hand, in its external self-identical sameness [the Parliament] resolves the reality of bourgeois society within its form.'
} 


\section{Translation-inflected language in original writing}

The intrusion of foreign words and new linguistic formations in Japanese has moved beyond the realm of translations. Levy suggests that translations that privilege foreign forms render 'the foreign text obsolete by offering it up for use (not merely 'knowledge' or aesthetic appreciation) in a new linguistic environment. Once the initial resistance to this kind of translation is overcome, its use by other writers will result in the transformation of the target language and thus, paradoxically, the complete naturalization of the foreign text to the native linguistic environment' (2006: 20). Although the completeness of this naturalizing process in Japan is open to debate, translational language has often been used in original writing, thereby constituting a broader sphere of translation-inflected style that does not derive from specific source text influences. According to Yanabu (1978a: 143), in fact, translational style is more common outside of translations, particularly in academic writing or writing on ideology.

Amongst the leading Meiji writers of literature who adopted a translation-influenced style were Futabatei Shimei-most notably in his novel Ukigumo (Floating Clouds; $1887)^{8}$ - and Mori Ōgai, with his blending of Japanese, Western and Chinese rhetorical conventions. The intricate descriptions of nature introduced through translations in Meiji times are an example of the aesthetic impact of translations on original writing. In the early twentieth century modernist writers drew on translation for inspiration, out of a belief that the new ideas and emotions of the modernizing nation called for new syntax and expressions, even if at first they might sound strange. For instance, in his 1913 translation of Flaubert's Salammbō, Ikuta Chōkō used literal translation of the original word order to achieve a distancing effect in an attempt at dai-nihongoka. One example was his translation of 'pétrifié de peur' [English: 'petrified'] as kyōfu ni kaseki shita, which is 'very weird and exotic indeed' (Keene 1980: 39). Satō Haruo's Supein ken no ie (The House of a Spanish Dog; 1917) skilfully employed a style absorbed from translated literature, using the present tense and expressions such as Soko de watashi wa soko o magaru (Inoue 1994: 338), while Yokomitsu Riichi's Naporeon to tamushi (Napoleon's Ringworm; 1926) made adept use of the effects found in literal translations of European works in an attempt to stimulate readers' senses.

Another example of translational language can be found in Hori Tatsuo's 1930 story

\footnotetext{
${ }^{8}$ See Cockerill (2006) for a full discussion of the impact of translation on Futabatei's writing.
} 
"Seikazoku" (Holy Family; 1949), with its abundance of pronouns and Frenchinfluenced word order. In Ambarvalia (1933), the much-praised and highly influential first poetry anthology in Japanese by Nishiwaki Junzaburō, original writing and translation combined to produce a new poetic language. Speaking of its newness, Hirata (1993: 49) observes:

in Nishiwaki's idiosyncratic use of translation, effecting a radical deformation and foreignization of the Japanese language ... some of the poems included in Ambarvalia are more or less direct translations of poems originally written in foreign languages by Nishiwaki himself. Consequently the text reveals a peculiar Japanese language, one willfully affected by Nishiwaki's sometimes extremely "literal" translations.

Keene (1987: 630) maintains that most modernist writers eventually 'reverted to older literary styles' because of the intractability of this idiom. Writing in the 1950s, however, Nakamura (1952: 1145) commented that the overall style of contemporary Japanese novels at that time was characterized by a kind of imitation translational style. This claim was substantiated by Mishima Yukio in his 1959 Bunshō tokuhon (1959/1973: 30-31), where he commented that translational-style writing had been regarded in a negative light before World War II, but after the war that was no longer the case. According to Mishima, authentic Japanese writing was now rare. Although highly critical of this translational style, Mishima himself deliberately tried to utilize the unnatural techniques of translated plays in his Sado kōshaku fujin (Madame de Sade; 1965), which was set in France.

The Nobel Prize-winner Ōe Kenzaburō is a contemporary author whose writing is often regarded as having been affected by foreign works and translations. As he says: 'My style is influenced by all the foreign-language literature I've read, but I first convert that into the Japanese literary style that's prevailed since the Meiji era ... and build my own style from there' (2007: 54). Thus Nathan (2000: 58) argues that it is 'nonsense' to describe Ōe's language as 'translationese' (Nathan's term). He suggests instead that Ōe uses translation to 'destabilize his own original, and thereby to discover new possibilities inherent in it ... a kind of simulacrum in Ōe of this interchange between the original and translation' (62). The recognition Ōe has won is indicative of the success of this creative approach.

According to Inoue (1996: 7), an affinity with translational style is evident in postwar writers such as Kurahashi Yumiko, Shōji Kaoru, Yoshimoto Banana ('who claims to 
have read nothing but comics and translated novels'), Shimada Masahiko ('who is feeling his way towards "a literature of artificial exile," free of the fetters of the Japanese language'), and Yamada Eimi ('who writes what can only be described as "English expressed in Japanese," or "translations for which there are no originals"'). Translations have also been influential in shaping the iconoclastic style of Murakami Haruki, who regards translation as his teacher (Kelts 1999). Murakami's writing style is very aware of European syntax. For instance, he uses long sentences, expressions that seem to be literal translations from English, and many personal pronouns, differentiating between the singular and plural first-person pronouns boku and bokutachi. The result is 'a detached, almost anesthetized narrative voice that sounds to the Japanese ear as if it were translated from another language' (Coleman 2000: 57).

\section{Changing attitudes}

Attitudes toward strangeness in translations can be expected to shift over time as a result of sociocultural changes or as the strangeness becomes assimilated and attenuated. Hon'yakuchō was particularly prominent in the Meiji period, when the content of translated texts (Western ideas and knowledge) was regarded as more important than the form (adherence to traditional style), and when translation was perceived as a way of enhancing the expressive capacities of the language in line with the needs of the modernizing nation. Translational language continued to be held in esteem in the Taishō period. Kobayashi (1995: 10) suggests that hon'yakuchō took on negative connotations in the Shōwa period-perhaps around the time when Akutagawa Ryūnosuke was criticized for the unnaturalness of his translation-like writing.

As noted above, however, in 1959 Mishima claimed that despite criticisms of translational language before World War II, it had become the mainstream style even for original writing. Yanabu (1978b: 16) subsequently took a different tack, suggesting that full assimilation of translational language into Japanese might be difficult even over a long period, just as the distinction between Japanese and Chinese writing had persisted in mixed Sino-Japanese. Yanabu (1978a: 143) believes that hon'yakuchō, which he refers to as a 'third language,' has obscured the fundamental differences between European languages and Japanese, blinding people to the difficulties or impossibility of translation. According to Yanabu, in Japan translation first occurs into this intermediate language, and it is only later that the smoothness of the translation as Japanese is 
considered (147). He argues that although the final stage is the most challenging, the initial stage determines how Japanese regard translation - there is a belief that a more or less mechanical substitution of words has already conveyed the meaning, so nothing further is necessary. Ōhashi (1978: 176) goes so far as to claim that any attempt to translate into pure Japanese today would result in a parody or distortion. Some contemporary critics continue to 'assume that the Japanese version [of foreign literature] should sound strange, that it should not sound like natural Japanese because it's foreign literature' (Hibbett 2000: 49). This suggests a residual awareness of the difference between translated Japanese and natural Japanese - not a resistance to translational Japanese, but a desire to mark its foreign origins.

Although the acceptance of opaqueness in loanwords remains strong, recent years have also seen increasing expectations of fluency in translations. As Inoue (1996: 7) argues:

\begin{abstract}
a loop of productive feedback has formed between the translation style of modern Japan and contemporary literature: translations have a revitalizing effect on the literature of the age, and the renewed vitality of contemporary literature is reflected in the literary style of new translations. The trend towards the unification of the written and spoken language is a good index of the yawning gulf between the original and the translation, which provides much of the creative tension that informs this feedback loop. When the gap becomes indistinct, the loop stops working. This means that the unification of the spoken and written languages is complete for the time being and that translation style has entered an age of stability ... such a dislocation occurred in the 1970s, between the two translation booms of the 1960s and the 1980s.
\end{abstract}

In the early 1990s a backlash against the stiffness of many translations appeared in the form of cho-hon'yaku ('ultra-translation'). This term was associated with the loose transcreations (total rewriting into a readable, idiomatic Japanese narrative) of Sidney Sheldon's novels. Satō (2000: 20) suggests that students today find the style of translations - especially their manner of description and expression-lacking in appeal. So perhaps Japan is becoming more like the Anglo-American translation world-even if the chö-hon'yaku phenomenon of the 1990s was limited in scope and impact and even if, as Venuti (1995) has argued, fluency is not necessarily a desirable quality. The

\footnotetext{
${ }^{9}$ By the 1960s Japanese society had achieved a certain stability, and the postwar gloom was replaced by a desire for more enjoyable works and an interest in becoming more cultured. The success of a five-volume anthology of non-fiction works from around the world, published by Chikuma Shobō in April 1960, led to the publication of numerous anthologies of world literature. The boom was accentuated by the comeback of translations of American novels and by translations of American works on management methods and the youth culture of the 1960s. In the 1980s the social cachet associated with reading foreign literary classics was replaced, to some extent, by interest in reading more popular American fiction, fostered in part by translations by Murakami Haruki and tie-ins with Hollywood movies. Translations of books for young readers, and translations of science fiction and the social sciences, were also popular, as were translated technical, economic and industrial books.
} 
weakening acceptance of translational language might be linked to Japan's growing cultural confidence. One outcome, however, is reduced opportunities to expand and reorient the Japanese language.

\section{Problematizing betweenness}

The notion of betweenness - an interlingual or interstitial 'mid-speech' (Steiner 1975: 333) — does, however, need reexamination. As noted in my introduction, the key question is whether hon'yakucho lies between the source language(s) and Japanese or is a part of the Japanese language. I concur with Nohara (1998) that the acceptance and importance of hon' yakuchō in Japan mean it is 'not a usage outside the entity of 'proper' language.' The domain of hon 'yakuchō is neither external to the Japanese language system nor marginalized, but an integral part that is even positioned close to and has influenced the mainstream, such that it almost provokes no strangeness any longer, even if it still triggers occasional criticism. In one sense, the foreignness inherent in hon'yakuchō paradoxically represents not heterogeneity, but a certain homogeneity in and of itself, since the linguistic features that mark hon 'yakuchō are so widely practised and accepted in translations and even original writing. It constitutes a (sub)norm whose transgressive thrust is not so much to violate Japanese norms as to transform them. Hon'yakuchō is not a space between, but a space within. And this interior space is not a hermetic compartment isolated from its surroundings, but a porous entity whose seepage affects the larger system within which it is located.

Discussing not hon'yakuchō specifically but the 'third space of translation' as a whole, Thornber suggests that rather than occupying a 'between' position, 'The third space of translation overlaps with and eventually subsumes the first and second spaces' (2008: 79). That is, by creating a third space, translations acknowledge the interdependence and textual intertwining of the source and target spaces, highlighting 'the artificiality of conventional categories and ... the need to understand cultural products as constantly moving, transforming entities, not as static artifacts in dusty archives that are best classified and examined along linguistic/cultural/national lines' (92).

If translators operate not in a space between the source language and target language, but in a system inclusive of both, then in what larger system might Japanese translators and writers who adopt hon 'yakuchō be operating? Does this consist of the pure 
language where meaning instantly becomes truth, as posited by Walter Benjamin in his seminal essay of 1923? Benjamin regarded translation as an attempt to integrate the many languages into one true language, and the aim of literal translation as allowing a glimpse into this pure language. Although many foreign-derived linguistic features are present in Japanese translations, they have not usually been regarded in Japan as an attempt to peel away the semantic accretions to reveal the underlayers of meaning. Ōe Kenzaburō, however, has claimed that translators exist in a special dark void between the language of the source text and the supposedly corresponding Japanese, and that this cultural no-man's-land is rich with potential for generating new things and is perhaps where lurk the universal properties of human language (uncited source mentioned in Yanabu 1978b: 9). Nonetheless the deliberate use of hon 'yakuchō seems to have been more motivated by a target-oriented aspiration to invigorate Japanese language and literature than by a desire to draw closer to the pure language purportedly underlying all human languages. Thus the outcome of translational language might conceivably represent a move toward pure language, if we accept that concept.

Although the term 'third code' is problematic in that it implies something external to the source and target languages, it is worth relating it to Homi Bhabha's concept of a 'third space' (1994: 36-39). For Bhabha, the third space refers to the non-fixedness of nontextual hybrid identity, which is 'celebrated as a privileged position of intelligence due to the advantages of in-betweenness and the ability therefore to negotiate the difference' (Fenton 2004: 5). Despite this non-linguistic focus, the third space 'results in the same cultural signs carrying different meanings on different occasions of their enunciation' (Batchelor 2008: 54) - a phenomenon that could be applicable to the foreign signs reenunciated in hon'yakuchō. As Wolf (2000: 141) argues:

\footnotetext{
The space-in-between is therefore a fertile and, at the same time, disquieting space where the dialectical interaction of at least two cultures takes place. It is a place where the dominant culture and language can be subverted, and thus functions as a sort of resistance. If we consider the Third Space as the potential and starting point for interventionist translation strategies, we realize that such strategies go far beyond the traditional concepts of 'original' and 'translation,' and the old dichotomy of 'foreignizing' versus 'domesticating' in all its implications. These strategies imply a shift toward the centre, where cultures encounter each other, and where meanings are effectively 'remixed.'
}

Batchelor has criticized Wolf's reading of Bhabha's third space because he conceives it 'primarily in spatial terms,' whereas Bhabha developed the concept in relation to 'the time-lag between event and enunciation' (2008: 54). Nevertheless, Wolf's notion of a 
cultural encounter and remixing of meanings is relevant to the Japanese situationalthough this occurs not in a 'space-in-between,' but within the target culture.

Some scholars have also considered the third space in relation to the figure of the translator. Tymoczko, however, argues against views of translators as agents positioned between the source and target languages, outside of their own culture and with no position in the other culture, as this would imply a lack of ideological engagement. She maintains that 'the translator is in fact all too committed to a cultural framework, whether that framework is the source culture, the receptor culture, a third culture, or an internal cultural framework that includes both source and receptor societies ... The ideology of translation is indeed a result of the translator's position, but that position is not a space between' (2003: 201). Although the metaphor of the translator as a 'bridge' between cultures is not uncommon in Japan, the notion of the translator as a hybrid figure privileged with the ability to negotiate between the source and target languages and cultures has not been a notable part of the Japanese discourse surrounding hon'yakuchō. Instead, the emphasis has been on how translators and writers have used hon'yakuchō within the Japanese language to redefine the contours of the language.

\section{Conclusion}

The existence of translational language means that translation in Japan cannot be regarded in clear-cut terms of source and target languages and that the notion of target language in Japan is not monolithic, but differentiated. The foreign-derived elements within Japanese translations and original writing introduce a certain bivocality. Furthermore, as Levy (2006: 4) points out, the recognition of translation as 'one of the key sources of stylistic originality in the target language, rather than simply a pale derivative of the "original" text,' upsets conventional notions of imitation and originality. Even if deliberate internalization and use of these foreign influences have not always met with creative success on the part of individual Japanese translators and writers, translational language has collectively acted as a creative medium for reorienting the Japanese language through incremental changes over time. In Japan translation-inflected language has not necessarily been regarded in a negative light or as something between or alien to the source and target languages, but as a vital part of the target language that has played a key role in reshaping the Japanese language and offering new ways of perceiving the world. 


\section{Reference List}

Batchelor, K. 2008, 'Third Spaces, Mimicry and Attention to Ambivalence: Applying Bhabhian Discourse to Translation Theory,' The Translator, vol. 14, no. 1, 51-70.

Benjamin, W. 1989 [1923], 'The Task of the Translator,' in Readings in Translation Theory, (ed.) A. Chesterman, Oy Finn Lectura, Helsinki, 13-24.

Bhabha, H. 1994, The Location of Culture. Routledge, London and New York.

Chang Nam Fung. 1998, "Politics and Poetics in Translation: Accounting for a Chinese Version of "Yes Prime Minister," The Translator, vol. 4, no. 2, 249-72.

Cockerill, H. 2006, Style and Narrative in Translations: The Contribution of Futabatei Shimei, St. Jerome, Manchester, UK; Kinderhook, USA.

Coleman, J. 2000, 'Eye of the Dark Soul,' The Courier Mail, 30 December, 57.

Devy, G. 1998, 'Translation Theory: An Indian Perspective,' in Translation: From Periphery to Centrestage, (ed.) T. Mukherjee, Prestige Books, New Delhi, 47-66.

Egoyama, T. 1964, 'Ōbun-myaku,' in Gendai-go no seiritsu, (eds) T. Motoki and E. Yoshimoto, Meiji Shoin, Tokyo, 131-53.

Fenton, S. (ed.) 2004, For Better or For Worse: Translation as a Tool for Change in the South Pacific, St. Jerome, Manchester, UK, and, Northampton, MA.

Furuno, Y. 2004, Changes in Translational Norms in Postwar Japan. PhD dissertation, University of Queensland. 2005, 'Translationese in Japan,' in Translation and Cultural Change, (ed.) E. Hung, John Benjamins, Amsterdam/Philadelphia, 147-60.

Futabatei, S. 1887, Ukigumo, Kinkōdō, Tokyo.

Hibbett, H. 2000, 'Howard Hibbett on Tanizaki Jun'ichiro,' in Words, Ideas, and Ambiguities, (ed.) D. Richie, Imprint Publications, Chicago, 35-50.

Hirano, Y. 1934, Nihon shihonshugi shakai no kikō. Iwanami Shoten, Tokyo.

Hirata, H. 1993, 'Violation of the Mother Tongue: Nishiwaki Junzaburō's Translatory Language in Ambarvalia,' Comparative Literature, vol. 45, no. 1, 47-70.

Hori, T. 1949 [1930], "Seikazoku," Hori Tatsuo Sakuhinshū, vol. 1, Kadokawa Shoten, Tokyo.

Horiguchi, D. 1924, Yoru hiraku. Shinchōsha, Tokyo.

Howland, D. 2002, Translating the West: Language and Political Reason in Nineteenth-Century Japan, University of Hawai'i Press, Honolulu.

Ikeyama, H. 1963, ‘Kyōzai toshite no hon'yakubun,' Kokubungaku: Kaishaku to kanshō, vol. 28, no. 1, 217-21.

Ikuta, C. 1913, Saramubō. Hakubunkan, Tokyo.

Inoue, K. 1994, “"Bunshō tokuhon” e no michi: Tanizaki Jun'ichirō to hon'yaku to iu "seido,"” in Kindai Nihon no hon'yaku bunka, (ed.) S. Kamei, Chūō Kōronsha, 335-62. 1996, 'Translated Literature in Japan,' The Japan Foundation Newsletter, vol. 24, no. 1, 1-7.

Isoya, T. 1978, in A. Yanabu, T. Isoya, \& G. Uchimura. 'Aratamete “Hon'yakuchō” wo tou (Dangi), Hon'yaku no sekai, no. 3, 6-21.

Kamei, S. (ed.). 1994, Kindai Nihon no hon'yaku bunka, Chūō Kōronsha, Tokyo.

Keene, D. 1980, Yokomitsu Riichi: Modernist, Columbia University Press, New York. 1987, Dawn to the West: Japanese Literature in the Modern Era, Henry Holt, New York.

Kelts, R. 1999, 'Heart of Darkness,' Kansai Time-Out, November.

Kimura, K. 1972, 'Nippon hon'yaku-shi gaikan,' in Meiji hon'yaku bungaku-shū: Meiji bungaku zenshū 7 , (ed.) K. Kimura, Chikuma Shobō, Tokyo, 375-94.

Kobayashi, K. 1995, 'Daisan no genba kara: Hon'yaku no naka no "Nihon bungaku,"' in Waseda bungaku, vol. 228, 8-29.

Kornicki, P. 1998, The Book in Japan, Brill, Leiden.

Koyano, A. 1997, 'Chokuyaku kara “chōyaku” e,' in Hon'yaku no hōhō, (eds) K. Kawamoto \& K. Inoue, University of Tokyo Press, Tokyo, 217-29.

Levy, I. 2006, Sirens of the Western Shore: The Westernesque Femme Fatale, Translation, and Vernacular Style in Modern Japanese Literature, Columbia University Press, New York.

Maruyama, M. and S. Katō (eds). 1998, Hon'yaku to Nihon no kindai, Iwanami Shinsho, Tokyo.

Mishima, Y. 1973 [1959], Bunshō tokuhon, Chūō bunko, Tokyo. 1965, Sado kōshaku fujin, Kawade Shobō, Tokyo.

Miura, A. 1979, 'The Influence of English on Japanese Grammar,' The Journal of the Association of Teachers of Japanese, vol. 14, no. 1, 3-30.

Nakamura, K. 1872, Jiyū no ri, Dōjinsha, Tokyo.

Nakamura, M. 1952, 'Kōgo-bun to gaikoku bungaku,' Bungaku, vol. 20, no. 12, 1144-48. 
Nathan, J. 2000, 'John Nathan on Mishima Yukio and Oe Kenzaburo'’ in Words, Ideas, and Ambiguities. (ed.) D. Richie, Imprint Publications, Chicago, 51-68.

Nishiwaki, J. 1933, Ambarvalia, Shiinoki Publication, Tokyo.

Nohara, K. 1998, 'Foreignization and/vs Domestication Strategies in Japanese Translation: The Linguistic and Cultural Embedding in Popular Literature,' Unpublished paper presented at CETRA Research Seminar in Translation Studies.

Ōe, K. 2007, 'Ōe Kenzaburō Looks Back—and Ahead,' interviewed by Ozaki Mariko, Japan Echo, vol. 34 , no. 3, 53-56.

Ōhashi, K. 1978, 'Hon'yaku to buntai,' in Buntai towa nanika, (eds) J. Yoshiyuki et al., Heibonsha, Tokyo, 175-83.

Satō, H. 1917, Supein ken no ie, in Yameru bara: Tanpenshū, Tenyūsha, Tokyo.

Satō, M. 2000, 'Japanese Adaptations of 19th Century and Early 20th Century Western Children's Literature,' in Reconstructing Cultural Memory, (eds) L. D’Hulst \& J. Milton, Rodopi: Amsterdam and Atlanta, GA, 143-53.

Savory, T. 1958, The Art of Translation, Jonathan Cape, London.

Schäffner, C. \& Adab, N. 2001, 'The Idea of the Hybrid Text in Translation: Contact as Conflict,' Across Languages and Cultures, vol. 2, no. 2, 167-80.

Schepers, G. 1989, 'Translating Kafka into Japanese,' Journal of Kafka Society of America, vol. 13, nos. $1-2,55-66$.

Schleiermacher, F. 1997 [1813], 'On the Different Methods of Translating,' in Western Translation Theory from Herodotus to Nietzsche, (ed.) D. Robinson, St. Jerome, Manchester, 225-38.

Shuttleworth, M., \& M. Cowie. 1997, Dictionary of Translation Studies, St. Jerome, Manchester.

Steiner, G. 1975, After Babel. Aspects of Language and Translation, Oxford University Press, Oxford and New York.

Sturrock, J. 1990, 'Writing between the Lines: The Language of Translation,' New Literary History, vol. 21, 993-1013.

Tanaka, K. 1982, 'Hon'yaku arekore,' in Hon'yaku, Iwanami Shoten, Tokyo, 194-99.

Thornber, K. 2008, "Translating, Intertextualizing, and the "Borders" of "Japanese Literature," PAJLS vol. 9, 76-92.

Toury, G. 1995, Descriptive Translation Studies and Beyond, John Benjamins, Amsterdam and Philadelphia.

Tymoczko, M. 2003, 'Ideology and the Position of the Translator: In What Sense is a Translator "In Between?," in Apropos of Ideology, (ed.) M. Pérez, St. Jerome: Manchester, UK, and Northampton, MA, 181-201.

Venuti, L. 1995, The Translator's Invisibility. Routledge, London.

Watanabe, K. 1982, 'Bungaku toshite no hon'yaku,' Hon'yaku. Iwanami Shoten, Tokyo, 381-87.

Wolf, M. 2000, 'The Third Space in Postcolonial Representation,' in Changing the Terms: Translating in the Postcolonial Era, (eds) S. Simon \& P. St-Pierre, University of Ottawa Press, Ottawa, 127-45.

Yanabu, A. 1978a, 'Hon'yaku no mondai,' in Nihongo kenkyū no shūhen, (eds) J. Itani et al., Iwanami Shoten, Tokyo, 130-53. 1978b, in A. Yanabu, T. Isoya \& G. Uchimura, 'Aratamete "Hon'yakuchō” wo tou (Dangi),' Hon'yaku no sekai, no. 3, 6-21. 1998, Hon'yakugo o yomu, Maruyama Gakugei Tosho, Tokyo.

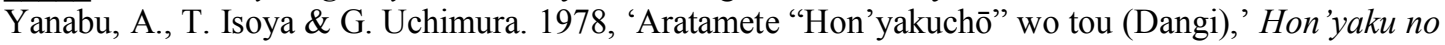
sekai no. 3, 6-21.

Yokomitsu, R. 1926, 'Naporeon to tamushi,' in Yokomitsu Riichi Zenshū vol. 6, Hibonkaku, Tokyo, 1936.

Yoshida, S. 1985, 'Eibun chokuyakutai ni tsuite,' Aichi Daigaku Bungaku Ronsō, vol. 80, December, 101-32. 